\title{
Особенности медийной кампании Евровыборы-2019 в Италии
}

Наталия Урина

Статья посвящена выявлению особенностей медийной кампании Евровыборы-2019 в Италии, а также своеобразию ее освещения в российских СМИ. В ней анализируется политико-медийная ситуация в Италии, роль и характер предвыборной тематики, место партийных лидеров в медийном пространстве. Ключевые слова: Евровыборы-2019, предвыборная кампания, медиа Италии, российские СМИ, лидеры партий. (c) Урина Наталия Валентиновна доктор филологических наук, старший научный сотрудник кафедры зарубежной журналистики и литературы факультета журналистики МГУ имени М.В. Ломоносова (г. Москва, Россия), natalia_urina@mail.ru
Медийные предвыборные кампании в современных условиях приобретают все большее значение. С одной стороны, они стандартизируются за счет использования новейших технологий, а с другой - в них в большей или меньшей степени просматривается национальный колорит. Выявление особенностей каждой такой кампании в отдельных странах представляет несомненную научную значимость и требует тщательного анализа деятельности СМИ. Пример итальянской кампании Евровыборы-2019 демонстрирует отличительные национальные черты, проявившиеся, в частности, в тематике дискуссий и медийной роли партийных лидеров. Существенным дополнением к таким исследованиям может служить изучение медийной реакции на выборы в странах, не входящих в Евросоюз. Исходя из этого, в предлагаемой статье в качестве дополнения рассматривается ее освещение в российских СМИ.

Роли СМИ в предвыборных кампаниях посвящено значительное количество исследований как в России, так и в Италии. В них рассматривается взаимодействие журналистики и политики в широком контексте (Корконосенко (ред.), 2004; Реснянская (ред.), 2007; Володенков, 2015), в европейском контексте (Громыко (ред.), 2014; Гуселетов, 2019; Швейцер, 2019), 
в национальном контексте Италии (Груша, Скрипкина, 2010; Урина, 2010, 2016). В ряду научно значимых работ особое место занимает сборник статей под редакцией Я.Н. Засурского «Выборы в новом медийном пространстве» (2015), в котором представлена масштабная картина избирательных кампаний в зарубежных странах в контексте обновляющейся стратегии политической коммуникаии и умножающейся роли СМИ.

В Италии эта тема разработана в многочисленных трудах по истории вопроса, в теоретическом, историческом и социологическом плане в рамках различных школ и научных подходов. Среди работ последнего времени можно отметить исследования М. Каччотто (2019), Дж. Паскино (2018), Л. Чеккарини и Дж. Невела (2019), в которых рассматриваются предвыборные кампании. Отдельного внимания заслуживает работа Л. Тентони «Европейские выборы в Италии. Пройденный путь между историей и датами» (2019).

Эмпирическую базу составили материалы итальянских и российских СМИ (апрель июнь 2019 г.) и результаты их контент-анализа, телемониторинги, предоставляемые Управлением по гарантиям в коммуникациях (Autorità per le garanzie nelle comunicazioni AgCom) и RAl (Radiotelevisione italiana), данные исследований различных научных центров Италии: Eurispes, аналитических отделов AgCom, DataMediaHub, Demos\&Pi, Associazione Italiana della Comunicazione Politica (AssoComPol), Osservatorio di Pavia и др. При изучении вопроса об освещении итальянских выборов в российских СМИ была задействована аналитическая система «Медиалогия».

\section{Политико-медийная ситуация в Италии}

В Италии базой выборов 2019 г. стали парламентские выборы 2018 г., которые изменили политическую карту страны, утвердив на ней "Движение 5 звезд"
(Д53) (Movimento 5 Stelle, M5S) в качестве лидера (более 32\%). Укрепила свою позицию «Лига» (Lega) во главе с M. Сальвини (17\%), а Демократическая партия (ДП) (Partito Democratico, PD) потеряла значительную часть электората (18\%)‥ В силу этого возникли трудности при формировании правительства, и коалиция «Лига»-Д53 с трудом нашла премьер-министра в лице Дж. Конте. Особенности политики правительства почти сразу проявились в решении как внутренних проблем, так и внешних, что свидетельствовало о недостатке взаимопонимания между членами коалиции.

Однако выборы 2019, несмотря на близость к предыдущим, внесли коррективы в расстановку сил на политической арене. Их результаты говорят о весомом успехе «Лиги» (34,26\%), некотором прогрессе ДП $(22,74 \%)$, уравновешенности «Вперед, Италия» (Forza Italia, FI) (8,78\%) и сокрушительном поражении Д53 (17,06\%)2. Италия, как и другие страны, меняется, но набор проблем, а также их порядок и сочетание имеют много отличий.

Важным фактором влияния на результаты Евровыборов является отношение итальянцев к Евросоюзу. Как показывают опросы, они относятся к числу скептиков по отношению к EC. По данным Demos\&Pi, в Германии ЕС доверяют 60\% жителей, в Голландии - 48\%, в Англии - 38\%, а во Франции и Италии - всего 34\%3. Интересна динамика доверия (см. рис. 1), которая свидетельствует о том, что оно интенсивно росло в Германии, в Великобритании имело небольшие колебания, во Франции падало, а в Италии обрушилось больше, чем вдвое - с 73\% до 34\% 4 .

Медийная составляющая итальянского общества трансформируется и оказывает воздействие на все сферы жизни. Написано уже немало трудов, в которых исследуются эти процессы. Получила продолжение традиция У. Эко теоретического и практического участия в деятельности СМИ. 


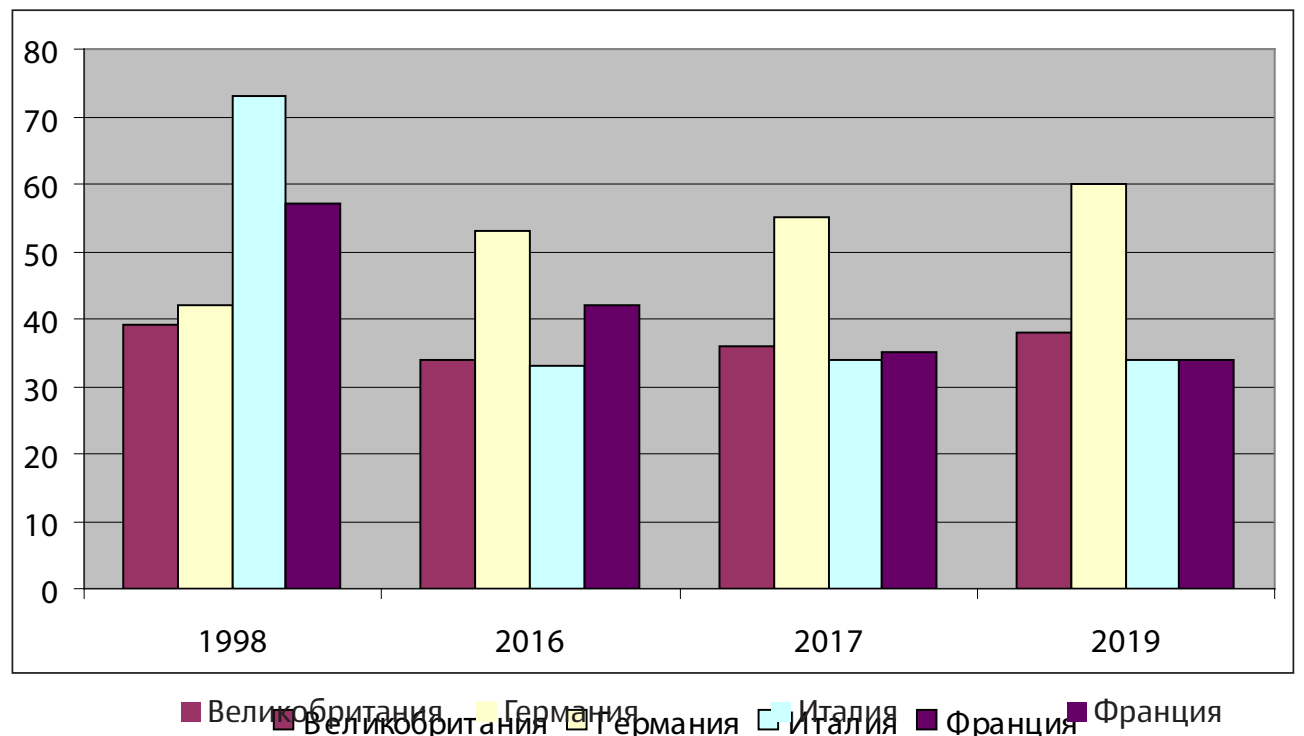

Рисунок 1. Доверие к ЕС (в \%)

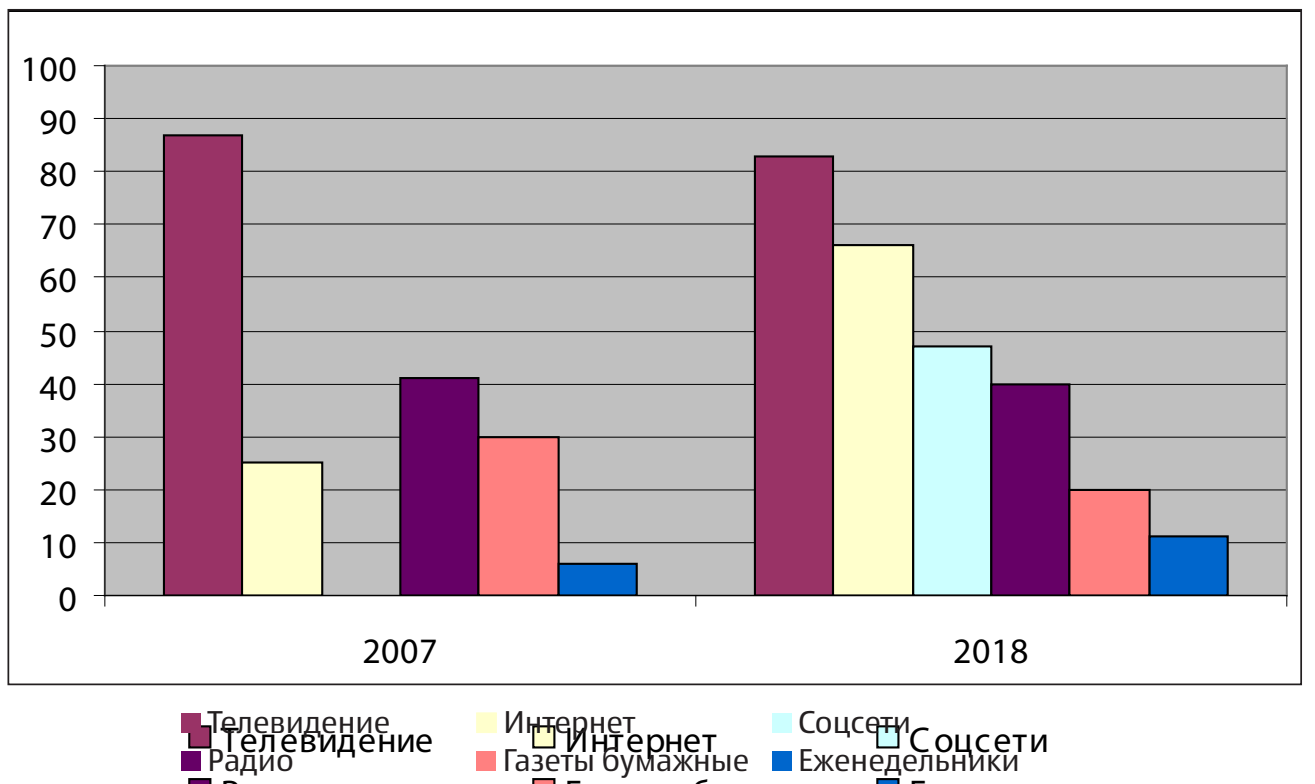

Рисунок 2. Ежедневное использование СМИ в Италии (в \%) 
В этом плане заслуживает внимания опыт одного из самых известных современных писателей А. Барикко. С одной стороны, он является автором оргинального сочинения под названием The Game5, в котором рассматриваются этапы развития высоких технологий и цифровизации общества, вовлеченного в своеобразную игру. С другой - в своей публицистике, в частности в серии статей в газете La Repubblica, он обращается к разрыву в обществе между элитами и остальными людьми. Применительно к Италии темы, анализируемые А. Барикко, весьма актуальны.

Его размышления подтверждаются многими процессами, которые на практике оказываются значительно более сложными, чем представления о них. В частности, они связаны с цифровизацией молодого поколения, которое должно принять эстафету от предшественников. Однако оно не всегда готово к этому и в результате теряет поддержку общества, особенно в политике. Важно и то, что в целом интернет-аудитория взрослеет. Ощутимы сдвиги от преимущественно молодежной аудитории к аудитории более солидного возраста по сравнению с тем временем, когда в 2009 г. Б. Грилло мобилизовал пользователей сети в партию Д53, получившую в 2018 г. наибольшее число голосов. Однако недостатки сетевой партии стали проявляться все более отчетливо, что способствовало выдвижению на первый план лигиста М. Сальвини под флагом «совранизма», т.е. суверенности. А молодой лидер сетевой партии Л. Ди Майо отошел на второй план. Для Д53 путь от «блога Грилло» до «платформы Руссо» оказался значительно более трудным, чем это представлялось несколько лет назад. Успех Д53, так впечатливший всех в 2018 г., не подтвердился ни на Евровыборах-2019, ни на региональных.

За последнее десятилетие к 2019 г. медийная ситуация в Италии претерпела определенные изменения, прежде всего связанные сувеличением онлайн-аудитории и сокращением числа читателей бумажных газет. Что касается телевидения и радио, то они понесли минимальные потери - $4 \%$ и $1 \%$ соответственно. Больше того - телевидение по-прежнему остается ведущим СМИ в Италии ${ }^{6}$ (см. рис. 2).

В контексте политических кампаний особое значение имеют пристрастия разных групп электората к отдельным СМИ, которые учитываются кандидатами (см. табл. 1). Так, электорат ДП наиболее традиционен в выборе СМИ, а Д53 - наиболее продвинут и больше ориентируется на Интернет. Это единственная партия, сторонники которой отдают предпочтение онлайн-пространству, а не телевидению, как все другие 7 .

\section{Предвыборная тематика и ее особенности в СМИ}

Евровыборы стали в Италии платформой для обсуждения как проблем EC, к которому у итальянцев прохладное отношение, так и собственных наболевших проблем. Безработица и климат, иммиграция и политичееская коррупция волнуют их значительно больше, чем кризис Европы (см. рис. 3).

В преддверии выборов первую пятерку составили вопросы, связанные с безработи цей $(22 \%)$, климатическими изменениями (13\%), неуверенностью в работе (10\%), иммиграцией (9\%) и налогами (9\%), а кризис Европы волновал только 3\% опрошенных. Также представляют интерес тематические предпочтения электората тех или других партий. Так, избирателей ДП больше всего волнует тема популизма, партий «Вперед, Италия» и Д53 - безработица, а приверженцев «Лиги» - иммиграция8.

На этом фоне особую актуальность и значимость приобретает вопрос о соотношении проблем, волнующих электорат, с медийной тематикой газет и телегазет. Что касается тематического своеобразия СМИ (см. рис. 4)9 ${ }^{9}$, то в газетах Corriere della sera, La Repubblica , La Stampa, Il Giornale, Il Fatto 
Таблица 1. Ежедневное использование СМИ электоратом отдельных партий (2018 г., в \%)

\begin{tabular}{|l|c|c|c|c|}
\hline \multicolumn{1}{|c|}{ сми } & дп & $\begin{array}{c}\text { Вперед, } \\
\text { Италия }\end{array}$ & Лига & д53 \\
\hline Телевидение & 87 & 87 & 88 & 79 \\
\hline Интернет & 58 & 61 & 75 & 81 \\
\hline Соцсети & 35 & 56 & 54 & 64 \\
\hline Радио & 46 & 23 & 45 & 48 \\
\hline Газеты бумажные & 29 & 20 & 20 & 15 \\
\hline Еженедельники & 13 & 11 & 14 & 13 \\
\hline
\end{tabular}

Источник: Demos \& Pi, 2 dicembre 2018. Режим доступа: http://www.demos.it/a01550.php

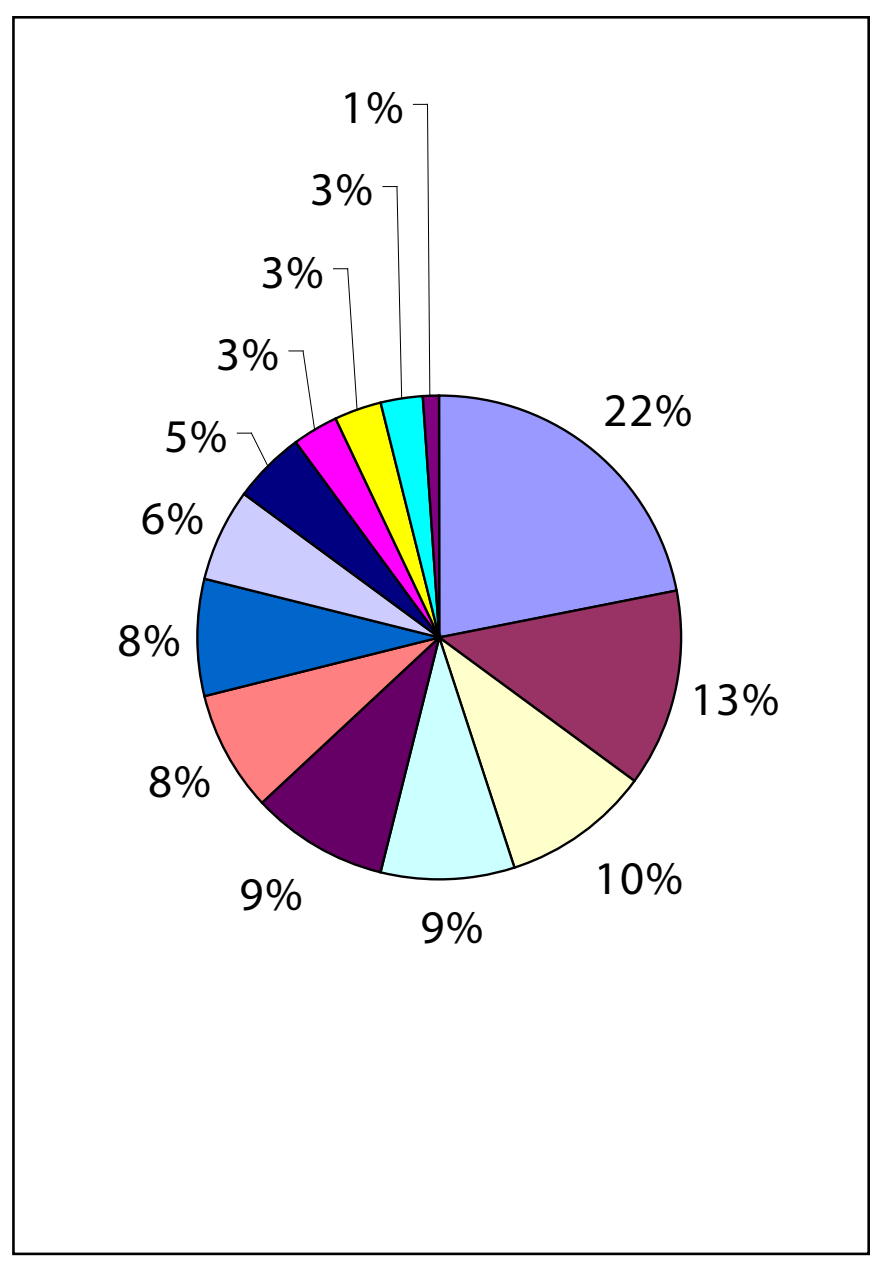

Безработица

Климатические изменения

Неуверенность

в работе

Иммиграция

Налоги

Терроризм

Политическая коррупция

Экономическиое развитие

— Организованная преступность

Кризис Европы

Популизм

Расизм

Другие темы

Рисунок 3. Темы, волнующие электорат (6-22 мая 2019 г.) 


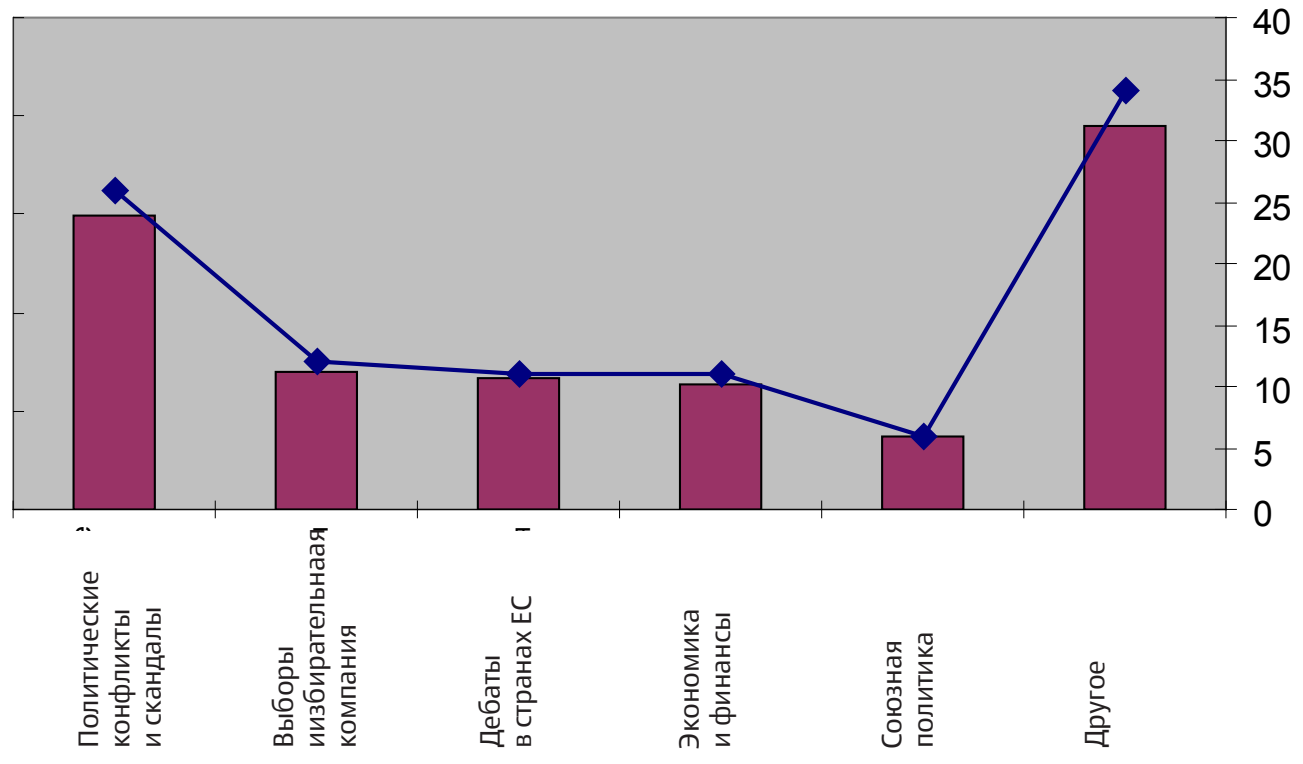

Рисунок 4. Темы в СМИ (телегазеты и газеты вместе, 7 апреля - 24 мая 2019 г.)

Quotidiano, телегазетах RAl, Mediaset и La7 наблюдается некоторая вариативность. Так, в первую пятерку тем Corriere della Sera L La Stampa не попала вторая («Выборы и избирательная компания»), четвертой («экономика и финансы») - нет в La Repubblica и Il Fatto Quotidiano. Исключение составляет лишь первая тема («политические конфликты и скандалы»), поскольку она первенствует во всех рассматриваемых изданиях.

Сравнительный анализ тематики материалов в названных выше СМИ и выступлений представителей электората показывает, что тематические приоритеты кандидатов и избирателей совпадали не всегда. Так, у первых превалировала тема политики, а у вторых - экономика и безработица. Первая тематическая пятерка не совпадает полностью, что в определенной мере объясняет несовпадение результатов выборов и основных тезисов медийной кампании ведущих газет и телегазет.

\section{Партийные лидеры и СМи}

Характер выборной кампании и ее результаты обусловлены не только самими лидерами партий и их программами, но и их медийными образами. Последние зависят от целого ряда факторов, начиная с того, какое место отведено политику в СМИ и особенно той тональности, которой окрашена его личность.

Все эти факторы являются существенными для понимания не только кампании, но и политической роли того или иного СМИ. Так, данные, представленные в таблице 2 , позволяют выявить позицию как газет, так и телегазет, еще раз подтвердив политизированность итальянской журналистики ${ }^{10}$.

Во всех анализировавшихся СМИ по объему материалов лидирует М. Сальвини (в интервале от 57\% в La Repubblica до 34\% в эфире TG5). Второе место занимает Ди Майо и третье Н. Дзингаретти. М. Сальвини опережает конкурентов также 
Таблица 2. Партийные лидеры в СМИ (объем и тональность материалов в \%)*

\begin{tabular}{|c|c|c|c|c|c|c|c|c|c|}
\hline \multirow[t]{3}{*}{ сми } & \multicolumn{3}{|c|}{ Ди Майо } & \multicolumn{3}{|c|}{ Сальвини } & \multicolumn{3}{|c|}{ Дзингаретти } \\
\hline & \multirow[t]{2}{*}{ Объем } & \multicolumn{2}{|c|}{ Тон } & \multirow[t]{2}{*}{ Объем } & \multicolumn{2}{|c|}{ Тон } & \multirow[t]{2}{*}{ Объем } & \multicolumn{2}{|c|}{ Тон } \\
\hline & & - & + & & - & + & & - & + \\
\hline Corriere della Sera & 33 & 10 & 2 & 51 & 25 & 6 & 6 & 11 & 2 \\
\hline La Repubblica & 28 & 34 & 1 & 57 & 50 & 2 & 10 & 46 & 30 \\
\hline La Stampa & 31 & 23 & 1 & 50 & 27 & 3 & 9 & 12 & 14 \\
\hline Il Giornale & 33 & 46 & - & 43 & 24 & 3 & 5 & 42 & 一 \\
\hline Il Fatto Quotidiano & 22 & 19 & 8 & 51 & 44 & 3 & 12 & 39 & 4 \\
\hline RAI (TGl) & 22 & 11 & 3 & 36 & 29 & 3 & 16 & 8 & 一 \\
\hline RAI (TG2) & 23 & 23 & 11 & 36 & 25 & 11 & 17 & - & 6 \\
\hline RAI (TG3) & 25 & 11 & 2 & 39 & 27 & - & 17 & 12 & 2 \\
\hline Mediaset (TG5) & 28 & 15 & - & 34 & 18 & 1 & 16 & 2 & - \\
\hline La7 News & 31 & 7 & 1 & 44 & 14 & 2 & 12 & - & 3 \\
\hline
\end{tabular}

* Таблица составлена по материалам исследования AssoComPol "Elezioni europee 2019. Media, Elettori", pp.42-43.

в отрицательной тональности (от $50 \%$ в той же La Repubblica до 14\% в новостях La7). А это говорит о том, что медиа, отводя ему много места, не ставили целью его поддержку. В положительнойтональности первенствовал Дзингарети в La Repubblica и La Stampa (30\% и 14\% соответственно), а Сальвини получил в этих газетах минимальный позитив (2\% и 3\%). Таким образом, ведущие издания и новостные телепрограммы в основном подтверждали свои политические позиции. Отчетливо продемонстрировала это левоцентристская La Repubblica.

Однако, учитывая кризис печати, можно говорить и о том, что позиции ведущих газет не играют прежней роли в политической борьбе. Но нельзя забывать и то, что идеи газет ретранслируются онлайн. Телевидение, конечно, сохраняет свое влияние, но позиции телегазет, тоже имеющих политические предпочтения, выражены не столь резко, как в газетах. На этом фоне особый интерес представляет активность лидеров в сетях. К удивлению, лидером в них выступает М. Сальвини, а не Л. Ди Майо, олицетворяющий сетевую партию Д53. Так, у М. Сальвини появился 661 пост на Facebook, 523 в Instagram и 1400 твиттов. у Ди Майо - 255, 55 и 11 соответственно, а у Н. Дзингаретти - 139, 99 и 10611.

Поскольку Facebook является самой популярной сетью в Италии, то представляется целесообразным рассмотреть тематику постов лидеров именно в этой сети и определить, насколько она отличается от газетной и телевизионной (см. табл. 3).

Как показывают данные таблицы ${ }^{12}$, тема «Предвыборная пропаганда», что вполне резонно, занимает первое место в постах трех лидеров. Последующая иерархия тем разнится. У Сальвини в первую пятерку входят «Безопасность», «Иммиграция" и «Экономика», что наиболее близко к ожиданиям электората. В определенной мере именно этим можно объяснить успех Сальвини на выборах. Показательно, что тема «Иммиграция» вообще отсутствует в постах Ди Майо и минимальна у Дзингаретти.

Предвыборная кампания в Интернете привлекла к себе внимание и в контексте растущего фактора «фейк ньюс». Так, в специальном исследовании AgCom были опубликованы данные о фейковых новостях в темах, имеющих отношение 
Таблица 3. Посты лидеров в Facebook и их тематика (28 апреля - 24 мая 2019 г.)

\begin{tabular}{|c|c|c|c|c|c|c|}
\hline \multirow[t]{2}{*}{ Тема } & \multicolumn{2}{|c|}{ Сальвини } & \multicolumn{2}{|c|}{ Ди Майо } & \multicolumn{2}{|c|}{ Дзингаретти } \\
\hline & Кол-во & $\%$ & Кол-во & $\%$ & Кол-во & $\%$ \\
\hline $\begin{array}{l}\text { Предвыборная } \\
\text { пропаганда }\end{array}$ & 406 & 61,42 & 134 & 53,17 & 63 & 45,32 \\
\hline Работа и развитие & 6 & 0,91 & 50 & 19,84 & 19 & 13,67 \\
\hline $\begin{array}{l}\text { Национальные } \\
\text { политические дебаты }\end{array}$ & 31 & 4,69 & 39 & 15,48 & 12 & 8,63 \\
\hline $\begin{array}{l}\text { Welfare, здоровье } \\
\text { и социальная политика }\end{array}$ & 8 & 1,21 & 5 & 1,98 & 5 & 3,60 \\
\hline Хроника & 17 & 2,57 & 5 & 1,98 & 1 & 0,72 \\
\hline Юстиция & 9 & 1,36 & 5 & 1,98 & 0 & 0,00 \\
\hline Ценности и права & 13 & 1,97 & 4 & 1,59 & 9 & 6,47 \\
\hline Экономика & 19 & 2,87 & 4 & 1,59 & 6 & 4,32 \\
\hline Безопасность & 58 & 8,77 & 3 & 1,19 & 13 & 9,35 \\
\hline Политика ЕС & 7 & 1,06 & 1 & 0,40 & 2 & 1,44 \\
\hline $\begin{array}{l}\text { Частная жизнь } \\
\text { и свободное время }\end{array}$ & 19 & 2,87 & 1 & 0,40 & 0 & 0,00 \\
\hline Рыбная ловля & 0 & 0,00 & 1 & 0,40 & 0 & 0,00 \\
\hline Зарубежные дела & 6 & 0,91 & 0 & 0,00 & 1 & 0,72 \\
\hline Защита & 7 & 1,06 & 0 & 0,00 & 0 & 0,00 \\
\hline $\begin{array}{l}\text { Инфраструктуры } \\
\text { и транспорт }\end{array}$ & 0 & 0,00 & 0 & 0,00 & 1 & 0,72 \\
\hline Окружающая среда & 2 & 0,30 & 0 & 0,00 & 3 & 2,16 \\
\hline Школа и образование & 5 & 0,76 & 0 & 0,00 & 1 & 0,72 \\
\hline Культура & 0 & 0,00 & 0 & 0,00 & 1 & 0,72 \\
\hline Иммиграция & 46 & 6,96 & 0 & 0,00 & 2 & 1,44 \\
\hline Сельское хозяйство & 2 & 0,30 & 0 & 0,00 & 0 & 0,00 \\
\hline Всего & 661 & 100 & 252 & 100 & 139 & 100 \\
\hline
\end{tabular}

Источник: AssoComPol. Elezioni europee 2019. Media, Elettori, Risultati, p.45. Режим доступа: https://www.compol. it/news/elezioni-europee-2019-media-elettori-risultati/

к европейским проблемам ${ }^{13}$ (май 2019). Они свидетельствуют, что наиболее уязвимыми для дезинформации оказались вопросы, связанные с преступностью, безработицей, иммиграцией, налогообложением и терроризмом, т.е. самые актуальные для итальянцев.

\section{Российские СМИ о выборах в Италии}

Евровыборы стали значительным по- лялись ее ролью международного партнера литическим событием 2019 г. Страны ЕС, европейских стран. Общей темой во всех

взбудораженные внутренними противоречиями, брекзитом, давлением со стороны США и экономическими проблемами, начали предвыборную кампанию задолго до ее официального старта. Ее течение привлекло внимание мирового сообщества и стало одной из актуальных тем в СМИ многих стран, в том числе и России.

Отношение России к выборам опреде- 
Таблица 4. Итальянская тематика в материалах, посвященных Евровыборам-2019 (СМИ РФ, 13 мая - 9 июня 2019 г.)

\begin{tabular}{|l|c|c|c|c|}
\hline \multirow{2}{*}{ Тематика } & \multicolumn{2}{|c|}{ Федеральные Сми } & \multicolumn{2}{c|}{ Региональные Сми } \\
\cline { 2 - 5 } & Кол-во материалов & \% & Кол-во материалов & $\%$ \\
\hline $\begin{array}{l}\text { Материалы, посвященные } \\
\text { Евровыборам } \\
\text { в целом }\end{array}$ & 5941 & 100 & 1835 & 100 \\
\hline $\begin{array}{l}\text { Материалы, посвященнные } \\
\text { выборам в Италии }\end{array}$ & 141 & 2,4 & 26 & 1,4 \\
\hline $\begin{array}{l}\text { Материалы, в которых } \\
\text { внимание акцентировано } \\
\text { на М. Сальвини }\end{array}$ & 65 & 1,1 & 15 & 0,8 \\
\hline
\end{tabular}

Источник: данные отчета системы «Медиалогия». 2019. Июнь, 10.

СМИ была Европа, ее политика и будущее. а в региональных - по 12 материалов и в Однако получил отражение и разный уро- той, и другой позиции. В них прежде всевень взаимодействия с отдельными странами - в экономической, политической и культурной сфере. Существующая напряженность во взаимоотношениях России со странами ЕС в значительной мере подпитывается скоординированной деятельностью мейнстримовских медиа, что наложило отпечаток на медийную тональность. Проведенный анализ российских СМИ позволяет определить особенности освещения Евровыборов как в целом, так и в отдельных странах (см. табл. 4).

Внимание российских СМИ к Италии можно назвать умеренным и по количеству сообщений, и по их тематике. Так, материалы, посвященные выборам в Италии, составили всего 2,4\% в федеральных СМИ и 1,4\% в региональных. Их тематика в основном была связана с предвыборной борьбой политиков, тяготеющих к евроскептицизму, и их успеху на выборах. Особое внимание в СМИ было уделено М. Сальвини, на долю которого пришлось еще 65 материалов $(1,1 \%)$ в федеральных СМИ и 15 в региональных $(0,8 \%)$.

Наибольшее количество материалов увидело свет на следующий день после выборов - 27 мая. В федеральных СМИ выборам в Италии в целом было посвящено 39 сообщений и 25 с акцентом на М. Сальвини, го отмечался успех лигистов и их лидера Сальвини. Примечательно, что итальянская тематика на федеральном уровне наиболее активно отслеживалась ИА Regnum: 46 материалов, посвященных выборам в Италии, и 33 - лидеру лигистов.

Следует отметить, что помимо материалов, в которых доминировала итальянская тематика и которые заняли скромное место в информационном потоке России, оценка ситуации в Италии в той или иной мере присутствовала в материалах обзорного характера, посвященных общеевропейским проблемам.

\section{Выводы}

Европейские выборы и их результаты отражают не только политическую картину той или другой страны, но и характер медийного участия в ее создании и своеобразии. Изучение итальянских СМИ дает основание сделать выводы о значительной роли в Евровыборах-2019 медиа и влиянии мейнстримовской информации, о тематической иерархии и о различиях в тональности. Особое значение приобретает выявление целенаправленной предвыборной дезинформации и вбросах фейковых новостей в медийное пространство. Проведенное исследование позволяет 
сделать определенные выводы, связанные с особенностями предвыборной кампании.

1) Политико-медийная ситуация в Италии претерпела в последние годы существенные изменения. Прежде всего продолжается переформатирование медийного арсенала: утрачивается влияние печати, сохраняется популярность телевидения, набирает силу и расширяет аудиторию Интернет. В ходе кампании были обозначены позиции евроскептиков и европеистов. Первые были представлены «Лигой» и ее лидером М. Сальвини, вторые- в основном ДП с Н. Дзингаретти и отчасти Д53 с Ди Майо. Однако европеизм не только не принес успеха Д53, но и обрушил ее популярность. Способствовало этому и то, что Ди Майо уступает Б. Грилло в роли публичного политика.

2) Освещение выборов в итальянских СМИ было широкоформатным, в нем участвовали все массмедиа и обсуждались разнообразные темы. В ходе кампании медийная тематика и тематика представителей электората показала, что для итальянцев отношение к Евросоюзу менее актуально, чем вопросы, связанные с безработицей, иммиграцией, терроризмом и т.д.

3) Участие лидеров партий в предвыборной кампании нашло отражение во всех СМИ. М. Сальвини и его позиция оказались ближе к интересам электората, чем у его партийных конкурентов. Сальвини лидировал не только в голосах избирателей, но и в Интернете, опережая представителя сетевой партии Ди Майо, а также в объеме информации и превалирующей негативной тональности в традиционных СМИ, большинство из которых придерживаются европеизма, следуя в русле европейских элит. В кампании М. Сальвини эти факторы сыграли очевидную роль. Ему не смогла помешать мейнстримовская печать, ТВ было более взвешенным, но не отдавало ему предпочтения. Интернет - свободная площадка, и Сальвини использовал ее более продуктивно, чем сетевик Ди Майо.

4) В российских средствах массовой информации выборы в Италии заняли скромное место. Несмотря на количественные и качественные различия в освещении этой кампании, очевидна общая тенденция внимание к М. Сальвини. Если в Италии оно было преимущественно негативным в традиционных СМИ, то в России - нейтральное с тенденцией к позитиву.

5) Проведенное исследование позволяет сделать вывод о том, что в предвыборной кампании роль медиа была обозначена весьма ощутимо и повлияла как на течение кампании, так и на ее результаты. В целом предвыборная кампания подтвердила, что несмотря на медийные трансформации и политические метаморфозы, в Италии сохраняется высокий уровень политизированности медийной сферы.

\section{Примечания}

${ }^{1}$ https//elezioni.repubblica.it/2018/cameradeideputati

2 https//www.corriere.it/elezioni-2019/europee-risultati/italia.shtml

3 Demos \& Pi, 15 aprile 2019. Ржим доступа: http://www.demos.it/a01594.php

4 Там же.

5 Baricco A. (2018) The Game. Torino: Einaudi.

6 Demos \& Pi, 2 dicembre 2018. Режим доступа: http://www.demos.it/a01550.php

7 Там же. 
8 AssoComPol. Elezioni europee 2019. Media, Elettori, Risultati, C. 30-31. Режим доступа: https://www.compol.it/news/elezioni-europee-2019-media-elettori-risultati/

9 Там же. С. 48.

10 Там же. С. 42-43.

11 Там же. С. 44.

12 Там же. С. 45.

${ }^{13}$ AgCom. Osservatorio sulla disinformazione, 2019, n. 4. Режим доступа: HYPERLINK "https://www.agcom.it/documentazione/documento?p_pauth=fLw/" https://www. agcom.it/documentazione/documento?p_pauth=fLw/

\section{Библиография}

Большая Европа. Идеи, реальность, перспективы: моногр. / под общ. ред. А.А. Громыко. М.: Весь мир; Ин-т Европы РАН, 2014.

Володенков С.В. Интернет-коммуникации в глобальном пространстве современного политического управления. М.: Изд-во Моск. ун-та; Проспект, 2015.

Выборы в новом медийном пространстве / под ред. Я.Н.Засурского. М.: ИКАР, 2015.

Груша А.В., Скрипкина Н.Н. Трансформация политической коммуникации: медиаобраз Сильвио Берлускони // Вестн. Моск. ун-та. Сер. 10: Журналистика. 2010. № 2. С. 9-22.

Гуселетов Б.П. Европейские выборы 2019 г.: статистика и прогнозы // Науч.-аналит. вестн. ИЕ РАН. 2019. № 3 (19). С. 11-16. DOI: HYPERLINK "http://dx.doi.org/10.15211/ vectybrieran320191116" 10.15211/vectybrieran320191116

Журналистика в мире политики: Исследовательские подходы и практика участия / ред.-сост. С.Г. Корконосенко. СПб.: Изд-во Михайлова В.А., 2004.

СМИ и политика / под ред. Л.Л. Реснянской. М.: Аспект Пресс, 2007.

Урина Н.В. Журналистика и политика: итальянский опыт взаимодействия. М.: ВК; Фак. журн. МГУ, 2010.

Урина Н.В. Роль СМИ Италии в предвыборных кампаниях (2013-2015 годы) // МедиаАльманах. 2016. № 1. С. 50-62.

Швейцер В.Я. Выборы 2019 года в Европейский парламент: партийно-политическая панорама // Современная Европа. 2019. № 1. C. 37-38. DOI: HYPERLINK "http:// dx.doi.org/10.15211/soveuropel20193847" 10.15211/soveurope120193847

Cacciotto M. (2019) Il nuovo marketing politico. Vincere le elezioni e governare al tempo della politica veloce. Bologna: ed. Il Mulino.

Ceccarini L., Newel J.L. (a cura di) (2019) Un territorio inesplorato. Le elezioni 4 marzo 2018. Santarcangelo di Romagna: Maggioli Editore.

Pasquino G. (2018) Vox populi. Il voto ad alta voce del 2018. Bologna: ed. Il Mulino.

Tentoni L. (2019) Le elezioni europee in Italia. Un percorso fra storia e dati 1979-2019. Bologna: Il Mulino. 